\title{
AIDS-Related Non-Hodgkin Lymphoma
}

National Cancer Institute

\section{Source}

National Cancer Institute. AIDS-Related Non-Hodgkin Lymphoma. NCI Thesaurus. Code C5051.

A non-Hodgkin lymphoma that develops in a patient with AIDS. 